\title{
КОМОРБДНІСТЬ ХРОНІЧНОГО ОБСТРУКТИВНОГО ЗАХВОРЮВАННЯ ЛЕГЕНЬ 3 АРТЕРІАЛЬНОЮ ГІПЕРТЕНЗІЄЮ: СТАН СИСТЕМИ АНТИОКСИДАНТНОГО ЗАХИСТУ
}

\section{Коморбідність хронічного обструктивного захворювання легень з артеріальною гіпертензією: стан системи антиоксидантного захисту \\ Х. Я. Максів, М. І. Марущак \\ Тернопільський національний медичний університет імені І. Я. Горбачевського МОЗ України}

Резюме. Відомо, що хронічне обструктивне захворювання легень (ХОЗЛ) асоціюється зі значною кількістю коморбідних станів, при цьому поширеність артеріальної гіпертензії (АГ) значно вища у хворих на хОзЛ. Спільними механізмами між більшістю цих позалегеневих проявів є хронічне системне запалення й оксидативний стрес.

Мета дослідження - оцінити стан антиоксидантної системи захисту в пацієнтів із коморбідним перебігом хронічного обструктивного захворювання легень й артеріальної гіпертензії.

Матеріали і методи. У дослідженні взяли участь 53 хворих на ХОЗЛ, 28 з яких мали артеріальну гіпертензію та перебували на стаціонарному лікуванні. Стан системи антиоксидантного захисту (АОЗ) оцінювали за активністю ензимів первинного захисту - супероксиддисмутази (СОД) і каталази, а також за вмістом церулоплазміну (ЦП).

Результати. При аналізі показників системи антиоксидантного захисту відмічено порушення антиоксидантних резервів у пацієнтів із ХОЗЛ та при коморбідності ХОЗЛ і АГ. Так, активність СОД при коморбідному перебігу ХОзЛ й АГ зменшувалася на 31,4 \%, тоді як активність каталази була вдвічі нижча проти даних контролю. Вміст ЦП у хворих на ХОЗЛ й АГ був вищий на 94,3 \% стосовно контрольних значень.

Висновки. Спільні фрактори ризику ХОЗЛ та $А Г$, посилення системного запалення при загостренні хОзЛ супроводжують каскадом патофрізіологічних механізмів, одним із яких є оксидативний стрес, який пов'язаний із виснаженням антиоксидантних резервів (вірогідне зниження активності супероксиддисмутази і каталази, підвищення вмісту церулоплазміну).

Ключові слова: хронічне обструктивне захворювання легень; артеріальна гіпертензія; коморбідність; антиоксидантна система захисту.
Comborbidity of chronic obstructive lung disease with arterial hypertension: the state of the antioxidant defense system

Kh. Ya. Maksiv, M. I. Marushchak

I. Horbachevsky Ternopil National Medical University e-mail: maksiv@tdmu.edu.ua

Summary It is known that chronic obstructive pulmonary disease (COPD) is associated with a considerable amount of comorbid conditions; herewith the prevalence of arterial hypertension $(A H)$ is significantly higher in patients with COPD. Common mechanisms between most of these extra-lung manifestations are chronic systemic inflammation and oxidative stress.

The aim of the study - evaluating the status of the antioxidant protection system in patients with a comorbid course of chronic obstructive pulmonary disease and hypertension.

Materials and Methods. The research included 53 patients with COPD, 28 of them had arterial hypertension and were at inpatient treatment. The condition of antioxidant protection system (AOP) was evaluated for the activity of primary protection enzymes - superoxide dismutases (SOD) and catalase, as well as the content of ceruloplasmin $(C P)$.

Results. In the analysis of indicators of the antioxidant protection system was noted the violation of antioxidant reserves in patients with COPD and with comorbidity COPD and $\mathrm{AH}$. So, the activity SOD at comorbidity course COPD and $A H$ decreased by $31.4 \%$, while catalase activity was twice lower against control data. The contents of CP in patients with COPD and $A H$ was higher by $94.3 \%$, in relation to control values.

Conclusions. The common risk factors of COPD and $A H$, intensification of systemic inflammation at aggravation COPD are accompanied by a cascade of pathophysiological mechanisms, one of them is oxidative stress, which is related to depletion of antioxidant reserves (likely decrease in activity of superoxide dismutases and catalase, increasing the content of ceruloplasmin).

Key words: chronic obstructive pulmonary disease; arterial hypertension; comorbidity; antioxidant defense system. 


\section{ВСТУП}

Враховуючи зростаючу поширеність тютюнокуріння [1], а також забруднення повітря [2], хронічне обструктивне захворювання легень (ХОЗЛ) виступає тихим вбивцею у країнах із низьким та середнім рівнем доходу. За оцінкою експертів, у 2016 р. 5 \% смертей в усьому світі були спричинені ХОЗЛ, з них 90 \% - у країнах з низьким і середнім рівнем доходу [3], хоча інші дані свідчать про високу смертність від ХОЗЛ також в економічно розвинутих регіонах [4]. Варто відмітити, що існує велика розбіжність у поширеності ХОЗЛ серед країн світу. Так, світова поширеність ХОЗЛ становить 9,2\%, тоді як у країнах Латинської Америки - 13,4 \% [5] порівняно 3 6 \% у США [6, 7] і 8,6 \% у Японії [8]. Кількість жителів Канади у віці 35 років і старше, які мають діагноз ХОЗЛ, збільшилася на 82 \%: з 1,1 млн (в період між 2000-2001 рр.) до трохи більше 2 млн (у 20122013 рр.) [9]. У 2016 р. поширеність ХОЗЛ в Індії становила 4,2 \%, що виводить дане захворювання на друге місце серед захворювань в Індії [10]. У Європі також спостерігається висока варіабельність поширення ХОЗЛ (від 4 до 10,2 \%) [11]. Статистичне дослідження, проведене в Англії, вказує, що близько 6 \% дорослого населення має ХОЗЛ [12]. У Греції поширеність ХОЗЛ, за різними даними, коливається в межах від 9,6 до 17,1 \% [13]. Дослідження CORE (Chronic Obstructive REspiratory diseases in CIS countries) показало, що поширення ХОЗЛ становило 10,4; 13,8 та 4,3 на 1000 населення відповідно в Україні, Казахстані та Азербайджані [14]

Відомо, що ХОЗЛ асоціюється зі значною кількістю коморбідних станів. Основними органами-мішенями при ХОЗЛ є бронхи і легені, але при цьому на певному етапі розвитку хвороби уражаються інші органи й системи. Як і очікувалося, найбільш значущу кореляцію виявлено між ХОЗЛ та серцево-судинними захворюваннями. Встановлено, що ХОЗЛ $€$ попередником розвитку серцево-судинних захворювань та/або його загострення $[15,16]$. Протягом останніх 30 років в Україні поширення серцево-судинних захворювань зросла в 3,5 раза, а рівень смертності від них - на $46 \%$. У структурі захворюваності першими $є$ гіпертонічна хвороба - 41 \% та ішемічна хвороба серця - 28 \% [17]. Поширення артеріальної гіпертензії також було значно вищим у хворих на ХОЗЛ [18]. Спільними механізмами між більшістю цих позалегеневих проявів $€$ хронічне системне запалення й оксидативний стрес $[19,20]$. Таким чином, коморбідність повинна розглядатися $з$ більшою увагою в стратегіях контролю ХОЗЛ і повинна бути важливою складовою коваріативних аналізів у дослідженні коморбідності [21].

Метою дослідження було оцінити стан антиоксидантної системи захисту в пацієнтів із комор- бідним перебігом хронічного обструктивного захворювання легень й артеріальної гіпертензії.

\section{МАТЕРІАЛИ I МЕТОДИ}

У дослідженні взяли участь 53 хворих на ХОЗЛ, 28 з яких мали артеріальну гіпертензію та перебували на стаціонарному лікуванні в пульмонологічному та кардіологічному відділеннях Тернопільської університетської лікарні з 2016 до 2019 р. Контрольну групу склали 20 практично здорових осіб. За віковим і статевим складом між групами хворих і практично здорових осіб істотної різниці не було. Усі пацієнти проінформовані про мету клінічного дослідження і дали письмову інформаційну згоду на свою участь у ньому. Конфріденційність інорормації про особу і стан здоров'я пацієнта були збережені.

Критерії включення в дослідження: пацієнти чоловічої статі, вік яких на момент обстеження в межах 40-60 років, встановлений діагноз ХОЗЛ згідно з наказами МОЗ України та рекомендаціями Європейського респіраторного товариства, підписання пацієнтом форми письмової інформованої згоди перед початком участі у дослідженні. Критерії виключення з дослідження: бронхіальна астма, дефіцит $\alpha_{1}$-антитрипсину, активний туберкульоз, рак легень, значні бронхоектази, саркоїдоз, фріброз легень, інтерстиційні захворювання легень; наявність ознак клінічно значущих неврологічних, психічних, ниркових, печінкових, імунологічних, шлунково-кишкових, сечостатевих розладів, ураження м'язово-скелетної системи, шкіри, органів чуття, ендокринної системи (неконтрольований діабет чи захворювання щитоподібної залози) або гематологічні захворювання, які $є$ неконтрольованими, нестабільне захворювання печінки, нестабільне або життєво небезпечне захворювання серця, пацієнти зі злоякісними новоутворенням, які не перебували у повній ремісії упродовж щонайменше 5 років, медикаментозна (наркотична) залежність, алкогольна залежність.

Діагноз ХОЗЛ встановлювали згідно з наказами МО3 України № 128 від 19 березня 2007 р. та МО3 України № 555 від 27 червня 2013 р. і рекомендаціями Американського респіраторного товариства, Європейського респіраторного товариства (GOLD, 2016) [22]. Ступінь обструкції дихальних шляхів встановлювали за класифікацією GOLD, 2016. У дослідження включили пацієнтів із ХОЗЛ, середнього ступеня обструкції (2 стадія) - ОФВ1 50-79 \%.

Діагноз артеріальної гіпертензії (АГ) । стадії встановлювали згідно з новими рекомендаціями ESC/ESH з АГ 2018 р., які представили на конгресі Європейського товариства кардіологів (ESC) [23]. Гіпертрофрію лівого шлуночка підтверджували електрокардіографрічно. 
Стан системи антиоксидантного захисту (АОЗ) оцінювали за активністю ензимів первинного захисту - супероксиддисмутази (СОД) і каталази, а також за вмістом церулоплазміну (ЦП). Активність сумарної СОД (КФ 1.15.1.1) у плазмі оцінювали за ступенем гальмування реакції окиснення кверцетину [24], активність КАТ (КФ 1.11.1.6) у сироватці за її здатністю розкладати гідрогену пероксид [25], вміст ЦП визначали - за окисненням френілендіаміндигідрохлориду при наявності ЦП [26].

Статистичну обробку результатів дослідження здійснювали за загальновизнаними методами варіаційної статистики 3 використанням програми STATISTICA 7. Кількісні характеристики ознак представляли у вигляді медіани та квартилів - Me (Lq; Uq).

\section{РЕЗУЛЬТАТИ ТА ОБГОВОРЕННЯ}

При аналізі показників системи антиоксидантного захисту відмічено порушення антиоксидантних резервів у пацієнтів із ХОЗЛ та при коморбідності ХОЗЛ і АГ. Так, активність СОД у першій дослідній групі була нижча на 20,8 \%, а в другій групі - на 31,4 \% стосовно контрольної групи. Зниження активності СОД у хворих на ХОЗЛ з поєднаним перебігом ХОЗЛ і АГ, на думку дослідників, може бути наслідком нездатності підтримки бар'єрних фрункцій еритроцитарною мембраною та її ушкодження продуктами пероксидного окиснення ліпідів [27]. Спрямованість змін активності каталази у дослідних групах також мала схожу динаміку. Так, у пацієнтів із ХОЗЛ відмічено вірогідне зменшення активності досліджуваного ензиму, а в пацієнтів із поєднаним перебігом ХОЗЛ і АГ активність каталази була вдвічі нижча проти даних контролю (табл.). Варто відмітити, що при коморбідному перебігу ХОЗЛ та АГ активність ензимів первинного захисту була вірогідно нижча стосовно даних у групі хворих на ХОЗЛ. Вміст церулоплазміну в першій дослідній групі був вищий на 37,1 \%, а у другій групі - на 94,3 \% стосовно контрольної групи. При цьому в пацієнтів із поєднаним перебігом ХОЗЛ і АГ його вміст у 1,9 раза перевищував дані першої дослідної групи.

У патогенезі ХОЗЛ вивчено чотири основні механізми, зокрема оксидативний стрес, запалення, дисбаланс протеазо-антипротеазної системи й апоптоз [28-30]. Вплив кожного з цих механізмів на розвиток і прогресування ХОЗЛ різний, проте центральну роль дослідники відводять оксидативному стресу, оскільки окрім прямої ушкоджувальної дії, він посилює три інші вказані механізми [31, 32]. Організм людини забезпечений рядом ендогенних ензимів, а також неензимних антиоксидантів, які нейтралізують вільні радикали. Як легені, так і кров, достатньо захищені цілим рядом неензимних речовин (наприклад аскорбінова кислота, $\alpha$-токофрерол, фреритин, сечова кислота) та ензимних антиоксидантів, таких, як СОД, каталаза та глутатіонпероксидаза, які можуть реагувати 3 гідроген пероксидом. Клітини альвеолярного епітелію II типу мають зазвичай більш щільно упаковані антиоксидантні ферменти, ніж альвеолоцити I типу. Каталаза, високореактивний внутрішньоцитоплазматичний ензим міститься як в альвеолярних макрофрагах II типу, так і у клітинах запального інфільтрату [33]. На думку дослідників, тютюнокуріння, як один з етіологічних чинників ХОЗЛ, може виснажити цей антиоксидантний захист і порушити механізми антиоксидантного захисту в пацієнтів цієї категорії [34]. СОД є у всіх клітинах дихальної системи і може перетворювати супероксид-аніон радикал у гідроген пероксид та оксиген. За даними різних авторів, у патогенезі ХОЗЛ найбільше значення мають манганзалежна й екстрацелюлярна СОД, які захищають альвеолярний епітелій легень $[35,36]$. Результати проведеного дослідження підтверджують виснаження пулу СОД, що може бути пов'язане 3 посиленим його використанням для нейтралізації вільних радикалів оксигену в пацієнтів із ХОЗЛ та при поєднанні ХОЗЛ й АГ.

Гідроген пероксид під дією каталази розкладається до 2 молекул води й оксигену. Каталаза міститься у більшості аеробних клітин та локалізована в пероксисомах (80 \%) і цитоплазмі (20\%). Невелика ії кількість може бути наявна в лізосомах і мітохондріях [37]. Каталаза належить до внутрішньоклітинних ензимів та через велику молекулярну масу погано проникає у позаклітинне середовище, де може швидко піддаватися протеолітичному розщепленню $[38,39]$. Звісно, що каталаза є синергістом СОД і між активностями цих фрерментів у нормі існує прямий кореляційний зв'язок, що пояснює спряжену дію ензимів СОД і каталази у хворих на ХОЗЛ. Отримані

Таблиця. Показники системи антиоксидантного захисту в пацієнтів при коморбідному перебігу хронічного обструктивного захворювання легень та артеріальної гіпертензії

\begin{tabular}{l|c|c|c}
\hline \multicolumn{1}{c|}{ Показник } & \multicolumn{3}{|c}{ Група } \\
\cline { 2 - 4 } & контрольна & ХОЗЛ (перша) & ХОЗЛ + АГ (друга) \\
\hline Активність СОД (ум. од. акт./мл) & $36,00(33,30 ; 39,50)$ & $28,52^{*}(26,80 ; 30,20)$ & $24,70^{* \#}(23,20 ; 26,10)$ \\
\hline Активність каталази (ум. од. акт./мл) & $1,19(1,02 ; 1,40)$ & $1,01^{*}(0,92 ; 1,12)$ & $0,59^{* *}(0,50 ; 0,68)$ \\
\hline Церулоплазмін (г/л) & $0,35(0,21 ; 0,31)$ & $0,48^{\star}(0,41 ; 0,54)$ & $0,68^{\star *}(0,60 ; 0,75)$ \\
\hline
\end{tabular}

Примітки 1) * - достовірність відмінностей порівняно $з$ контрольною групою;

2) \# - достовірність відмінностей між дослідними групами.

ISSN 2706-6282(print)

ISSN 2706-6290(online)
Вісник медичних і біологічних досліджень Bulletin of Medical and Biological Research
1,2019 
результати підтверджують інші дослідження [40, 41]. Варто відмітити суперечливі наукові дані щодо активності каталази у хворих на АГ $[42,43]$, проте ми встановили, що коморбідний перебіг ХОЗЛ і АГ поглиблює недостатність антиоксидантного захисту.

Антиоксидантна роль ЦП пов'язана 3 його оксидазною активністю, яка спрямована на ароматичні аміни і феноли, а також через фрероксидазну активність [27]. Зростання вмісту ЦП може виступати критерієм активації пероксидного окиснення ліпідів, а також нездатності АОС нейтралізувати надлишок вільних кисневих радикалів у пацієнтів із ХОЗЛ та коморбідним перебігом ХОЗЛ і АГ.

\section{ВИСНОВКИ}

Спільні фрактори ризику ХОЗЛ та АГ, посилення системного запалення при загостренні ХОЗЛ супроводжуються каскадом патофрізіологічних механізмів, одним із яких є оксидативний стрес, який пов'язаний із виснаженням антиоксидантних резервів (вірогідне зниження активності супероксиддисмутази і каталази, підвищення вмісту церулоплазміну).

\section{СПИСОК ЛІТЕРАТУРИ}

1. WHO global report on trends in prevalence of tobacco smoking. 2015.

2. Respiratory risks from household air pollution in low and middle income countries. / S. B. Gordon, N. G. Bruce, J. Grigg [at al.] // Lancet Respir. Med. - 2014. - No. 2 (10). - P. 823-860.

3. Chronic obstructive pulmonary disease (COPD). Access mode : https://www.who.int/news-room/fact-sheets/ detail/chronic-obstructive-pulmonary-disease-(copd).

4. Economic burden of chronic respiratory diseases in Austria and Slovenia Results of a life-cycle model / M. Pock, T. Czypionka, M. Reiss, G. Röhrling [et al.] // 2018. - Access mode : http://irihs.ihs.ac.at/4663/1/2018-ihs-report-pockczypionka-reiss-copd-chronic-respiratory-diseases-austriaslovenia.pdf.

5. Chronic obstructive pulmonary disease mortality and prevalence: the associations with smoking and poverty - a BOLD analysis / P. Burney, A. Jithoo, B. Kato [et al.] // Thorax. - 2014. - No. 69. - P. 465-473.

6. The epidemiology and burden of COPD in Latin America and the Caribbean: systematic review and meta-analysis / A. Ciapponi, L. Alison, M. Agustina [et al.] // COPD. - 2014. - No. 11. - P. 339-350.

7. Diaz-Guzman E. Epidemiology and prevalence of chronic obstructive pulmonary disease / E. Diaz-Guzman, D. M. Mannino // Clin. Chest Med. - 2014. - No. 35. P. 7-16.

8. COPD in Japan: the Nippon COPD epidemiology study / Y. Fukuchi, M. Nishimura, M. Ichinose [et al.] // Respirology. - 2004. - No. 9. - P. 458-465.

9. Canadian Chronic Disease Surveillance System (CCDSS). - Access mode : https://infobase.phac-aspc. gc.ca/ccdss-scsmc/data-tool/.

10. The burden of chronic respiratory diseases and their heterogeneity across the states of India: the Global Burden of Disease Study 1990-2016 / India State-Level Disease Burden Initiative CRD Collaborators // Lancet Glob Health. - 2018. - Vol. 6 (12). - P. 1363-1374.

11. Global and regional estimates of COPD prevalence: systematic review and meta-analysis / D. Adeloye, S. Chua, C. Lee [et al.] // J. Glob. Health. - 2015. - No. 5. - 020415.

12. Work-related Chronic Obstructive Pulmonary Disease (COPD) in Great Britain 2018. - Retrieved from: http://www.hse.gov.uk/statistics/causdis/copd.pdf.

13. Impact of the financial crisis on COPD burden: Greece as a case study / O. S. Kotsiou, S. Zouridis, M. Kos-

mopoulos [et al.] // European Respiratory Review. - 2018. - No. 27 (147). - P. 170106.

14. The prevalence, burden and risk factors associated with chronic obstructive pulmonary disease in Commonwealth of Independent States (Ukraine, Kazakhstan and Azerbaijan): results of the CORE study / D. Nugmanova, Y. Feshchenko, L. Iashyna [et al.] // BMC Pulm. Med. 2018. - No. 18 (1). - P. 26.

15. Calverley P.M. Is airway inflammation in chronic obstructive pulmonary disease (COPD) a risk factor for cardiovascular events? / P. M. Calverley, S. Scott // COPD. 2006. - No. 3 (4). - P. 233-242.

16. Risk factors for cardiovascular disease in patients with COPD: mild-to-moderate COPD versus severe-to-very severe COPD / L. M. Caram, R. Ferrari, C. R. Naves [et al.] // J. Bras. Pneumol. - 2016. - No. 42 (3). - P. 179-184.

17. Превентивна кардіологія: імплементація міжнародних рекомендацій в Україні / Асоц. кардіологів України, ВГО "Превент. кардіологія та реабілітація" [авт.-уклад.: В. М. Коваленко та ін.]. - Київ : МОРІОН, 2015. - 103 с.

18. Prevalence of comorbidities in chronic obstructive pulmonary disease patients: A meta-analysis / $\mathrm{H}$. Yin, S. Yin, Q. Lin [et al.] // Medicine (Baltimore). - 2017. No. 96 (19). - e6836.

19. Comorbidities of COPD / A. Cavaillès, G. BrinchaultRabin, A. Dixmier [et al.] // European Respiratory Review. 2013. - No. 22. - 454-475.

20. Марущак М. І. Роль активних фрорм кисню у розвитку і про-гресуванні гострого ураження легень в експерименті / М. І. Марущак // Медична хімія. - 2012. T. 14, № 1(50). - C. 104-108.

21. The influence of co-morbidity on health-related quality of life in asthma and COPD patients / $\mathrm{H}$. A. Wijnhoven, D. M. Kriegsman, A. E. Hesselink [et al.] // Respir. Med. - 2003. - No. 97 (5). - P. 468-475.

22. Global Initiative for Chronic Obstructive Lung Disease (GOLD) 2016. - Access mode : www.goldcopd.org.

23. ESC/ESH Guidelines for the management of arterial hypertension / B. Williams, G. Mancia, W. Spiering [et al.] // European Heart Journal. - 2018. - No. 39 (33). P. 3021-3104.

24. Костюк В. А. Простой и чувствительный метод определения супероксиддисмутазы, основанный на реакции окисления кверцетина / В. А. Костюк, А. И. Потапович, Ж. В. Ковалева // Вопросы медицинской химии. - 1990. - № 32. - C. 88-91. 
25. Метод определения активности каталазы / М. А. Королюк, А. И. Иванова, И. Г. Майорова [и др.] // Лаб. дело. - 1988. - № 1. - С. 16-19.

26. Арутюнян А. В. Методы оценки свободно-радикального окисления и антиоксидантной системы организма / А. В. Арутюнян, Е. Е. Дубинина, Н. Н. Зыбина. - СПб. : Фолиант, 2000. - 104 с.

27. Івчук В. В. Оксидантно-антиоксидантна система при хронічному обструктивному захворюванні легень профресійної етіології / В. В. Івчук, Т. А. Ковальчук // Медична та клінічна хімія. - 2019. - Т. 21, № 2. - С. 61-67.

28. Tuder R. M. Pathogenesis of chronic obstructive pulmonary disease / R. M. Tuder, I. Petrache // J. Clin. Invest. - 2012. - No. 122 (8). - P. 2749-2755.

29. Lee J. H. Pathogenesis of COPD / J. H. Lee // COPD Springer, Berlin, Heidelberg. - 2017.

30. Maksiv C. Y. The role of oxidative stress in the development of chronic obstructive pulmonary diseases / C. Y. Maksiv, M. I. Marushchak // Medical and Clinical Chemistry. - 2019. - No. 1. - P. 120-125.

31. Cavalcante A. G. The role of oxidative stress in COPD: current concepts and perspectives / A. G. Cavalcante, P. F. de Bruin // J. Bras. Pneumol. - 2009. - No. 35 (12). - Р. 1227-1237.

32. Патогенетична роль нейтрофрільних гранулоцитів у розвитку гострого ураження легень / А. А. Гудима, М. І. Марущак, Г. Г. Габор [та ін.] // Буковинський медичний вісник. - 2011. - № 3 (59). - C. 82-85.

33. Domej W. Oxidative stress and free radicals in COPD-implications and relevance for treatment / W. Domej, K. Oettl, W. Renner // International journal of chronic obstructive pulmonary disease. - 2014. - No. 9. - P. 12071224.

34. Nadeem A. Increased oxidative stress and altered levels of antioxidants in chronic obstructive pulmonary disease / A. Nadeem, H. G. Raj, S. K. Chhabra // Inflammation. - 2005. - No. 29 (1). - P. 23-32.

\section{REFERENCES}

1. WHO global report on trends in prevalence of tobacco smoking. 2015.

2. Gordon SB, Bruce NG, Grigg J, Hibberd PL, Kurmi OP, Lam KB, Mortimer K. Respiratory risks from household air pollution in low and middle income countries. Lancet Respir Med. 2014; 2(10): 823-60.

3. Chronic obstructive pulmonary disease (COPD). Available at: https://www.who.int/news-room/fact-sheets/ detail/chronic-obstructive-pulmonary-disease-(copd).

4. Pock M, Czypionka T, Reiss M, Röhrling G. Economic burden of chronic respiratory diseases in Austria and Slovenia Results of a life-cycle model. 2018. Available at: http:// irihs.ihs.ac.at/4663/1/2018-ihs-report-pock-czypionka-reisscopd-chronic-respiratory-diseases-austria-slovenia.pdf.

5. Burney P, Jithoo A, Kato B, Janson C, Mannino D, Nizankowska-Mogilnicka E, Studnicka M, et al. Chronic obstructive pulmonary disease mortality and prevalence: the associations with smoking and poverty - a BOLD analysis. Thorax. 2014; 69: 465-73.

6. Ciapponi A, Alison L, Agustina M, Demián G, Silvana C, Edgardo $S$. The epidemiology and burden of COPD in Latin
35. Smoking and COPD increase sputum levels of extracellular superoxide dismutase / E. A. Regan, W. Mazur, E. Meoni [et al.] // Free Radic. Biol. Med. - 2011. - No. 51 (3). - P. 726-732.

36. Лемко О. І. Деякі аспекти етіології, патогенезу та перебігу хронічного обструктивного захворювання легень (частина II) / О. І. Лемко // Науковий вісник Ужгородського університету, серія «Медицина». - 2013. № 1 (46). - С. 197-207.

37. Окислительный стресс. Прооксиданты и антиоксиданты / Е. Б. Меньщикова, В. 3. Ланкин, Н. К. Зенков [и др.]. - М. : Фирма «Слово», 2006. - 556 с.

38. Reactive oxygen species: from health to disease / K. Brieger, S. Schiavone, F. J. Miller [at al.] // Swiss. Med. Wkly. - 2012. - Vol. 142. - P. w13659.

39. Limon-Pacheco J. The role of antioxidants and antioxidant-related enzymes in protective responses to environmentally induced oxidative stress / J. Limon-Pacheco, M. E. Gonsebatt // Mutation Research. - 2009. - Vol. 674. - P. 137-147.

40. Ahmad A. Relation of oxidant-antioxidant imbalance with disease progression in patients with asthma / A. Ahmad, M. Shameem, Q. Husain // Ann. Thorac Med. - 2012. - No. 7. - P. 226-232.

41. Evaluation of oxidative stress and antioxidant status in chronic obstructive pulmonary diseases / S. K. Singh, S. Verma, M. K. Kumar [et al.] // Dixit Scandinavian Journal of Immunology. - 2017. - No. 85 (2). - P. 130-137.

42. КовальоваО.М. Рівень 8-ізопростанутаактивність супероксиддисмутази і каталази у хворих на гіпертонічну хворобу з надмірною масою тіла й ожирінням на фоні комбінованої антигіпертензивної терапії / О. М. Ковальова, Н. М. Герасимчук, Н. А. Сафраргаліна-Корнілова // Експериментальна і клінічна медицина. - 2013. - № 2 (59). - C. 86-92.

43. Biomarkers of antioxidant status and lipid peroxidation in elderly patients with hypertension / H. Pawluk, R. Pawluk, J. Robaczewska [et al.] // Redox Report. - 2017. - No. 22 (6). - P. 542-546.

America and the Caribbean: systematic review and metaanalysis. COPD. 2014;11: 339-50.

7. Diaz-Guzman E, Mannino DM. Epidemiology and prevalence of chronic obstructive pulmonary disease. Clin Chest Med. 2014;35: 7-16.

8. Fukuchi $Y$, Nishimura $M$, Ichinose $M$, Adachi $M$, Nagai A, Kuriyama T, Takahashi $\mathrm{K}$ et al. COPD in Japan: the Nippon COPD epidemiology study. Respirology. 2004;9: 458-65.

9. Canadian Chronic Disease Surveillance System (CCDSS). Available at: https://infobase.phac-aspc.gc.ca/ ccdss-scsmc/data-tool/.

10. India State-Level Disease Burden Initiative CRD Collaborators. The burden of chronic respiratory diseases and their heterogeneity across the states of India: the Global Burden of Disease Study 1990-2016. Lancet Glob Health. 2018;6: e1363-74.

11. Adeloye D, Chua S, Lee C, Basquill C, Papana A, Theodoratou E, Nair H, et al. Global and regional estimates of COPD prevalence: systematic review and meta-analysis. J Glob Health. 2015; 5:020415. 
12. Work-related chronic obstructive pulmonary disease (COPD) in Great Britain, 2018; http://www.hse.gov. uk/statistics/causdis/copd.pdf

13. Kotsiou OS, Zouridis S, Kosmopoulos M, Gourgoulianis $\mathrm{KI}$. Impact of the financial crisis on COPD burden: Greece as a case study. European Respiratory Review Mar. 2018; 27(147): 170106

14. Nugmanova D, Feshchenko Y, lashyna L, Gyrina O, Malynovska K, Mammadbayov E, Akhundova I, et al. The prevalence, burden and risk factors associated with chronic obstructive pulmonary disease in Commonwealth of Independent States (Ukraine, Kazakhstan and Azerbaijan): results of the CORE study. BMC Pulm Med. 2018;18(1): 26. doi: 10.1186/s12890-018-0589-5.

15. Calverley PM, Scott S. Is airway inflammation in chronic obstructive pulmonary disease (COPD) a risk factor for cardiovascular events? COPD. 2006;3(4): 233-42. doi: 10.1080/15412550600977544.

16. Caram LM, Ferrari R, Naves CR, Coelho LS, Vale SA, Tanni SE, Godoyl. Risk factors for cardiovascular disease in patients with COPD: mild-to-moderate COPD versus severe-to-very severe COPD. J Bras Pneumol. 2016;4 2(3): 179-84.

17. Prevent Cardiology and Rehabilitation Association [authored by: VM Kovalenko and others]. Preventive cardiology: implementation of international recommendations in Ukraine. [Превентивна кардіологія: імплементація міжнародних рекомендацій в Україні] Kyiv: MORION; 2015. Ukrainian.

18. Yin H, Yin S, Lin Q, Xu Y, Xu H, Liu T. Prevalence of comorbidities in chronic obstructive pulmonary disease patients: A meta-analysis. Medicine (Baltimore). 2017;96(19): e6836.

19. Cavaillès A, Brinchault-Rabin G, Dixmier A, Goupil F, Gut-Gobert C, Marchand-Adam S, Meurice JC, et al. Comorbidities of COPD. European Respiratory Review. 2013;22: 454-75.

20. Marushchak MI. [The role of reactive oxygen species in the development and progression of acute lung injury in experiment]. Med khim. 2012;1(50): 104-08. Ukrainian.

21. Wijnhoven HA, Kriegsman DM, Hesselink AE, de Haan M, Schellevis FG. The influence of co-morbidity on health-related quality of life in asthma and COPD patients. Respir Med. 2003;97(5): 468-75.

22. Global Initiative for Chronic Obstructive Lung Disease (COLD). 2016; Available at: www.goldcopd.org.

23. Williams B, Mancia G, Spiering W, Rosei EA, Azizi M, Burnier M, Clement DL, et al. ESC/ESH Guidelines for the management of arterial hypertension. European Heart Journal. 2018;39(33): 3021-104.

24. Kostiuk VA, Potapovich Al, Kovaleva Zh. [A simple and sensitive method for the determination of superoxide dismutase based on the quercetin oxidation reaction]. Vopr med khim. 1990;32: 88-91. Russian.

25. Korolyuk MA, Ivanova AI, Mayorova IG. [Method for determination of catalase activity]. Lab delo. 1988;1: 16-19. Russian.

26. Harutyunyan AB, Dubinina EE, Zybina NN. Methods for assessing free radical oxidation and the antioxidant system of the body. [Методы оценки свободно-радикального окисления и антиоксидантной системы организма] Saint-Petersburg: Folio; 2000. Russian.
27. Ivchuk BB, Kovalchuk TA. [Oxidant-antioxidant system in chronic obstructive pulmonary disease of professional etiology]. Med i klin khim. 2019;21(2): 61-7. Ukrainian.

28. Tuder RM, Petrache I. Pathogenesis of chronic obstructive pulmonary disease. J Clin Invest. 2012;122(8): 2749-55.

29. Lee JH. Pathogenesis of COPD. COPD Springer, Berlin, Heidelberg. 2017.

30. Maksiv CY, Marushchak MI. The role of oxidative stress in the development of chronic obstructive pulmonary diseases. Medical and Clinical Chemistry. 2019;1: 120-25.

31. Cavalcante AG, de Bruin PF. The role of oxidative stress in COPD: current concepts and perspectives. J Bras Pneumol. 2009; 35(12): 1227-37.

32. Hudyma AA, Marushchak MI, Habor HH, Kulitska MI. [Pathogenetic role of neutrophil granulocytes in the development of acute lung injury]. Bukov med visn. 2011;3(59): 82-5.

33. Domej W, Oettl K, Renner W. Oxidative stress and free radicals in COPD-implications and relevance for treatment. International journal of chronic obstructive pulmonary disease. 2014;9: 1207-24. doi :10.2147/COPD.S51226.

34. Nadeem A, Raj HG, Chhabra SK. Increased oxidative stress and altered levels of antioxidants in chronic obstructive pulmonary disease. Inflammation. 2005;29(1): 23-32.

35. Regan EA, Mazur W, Meoni E, Toljamo T, Millar J, Vuopala K, Bowler RP, et al. Smoking and COPD increase sputum levels of extracellular superoxide dismutase. Free Radic Biol Med. 2011;51(3): 726-32.

36. Lemko OI. Some aspects of the etiology, pathogenesis and course of chronic obstructive pulmonary disease (Part II). Nauk visn Uzhhorod un-tu. 2013;1(46): 197-207. Ukrainian.

37. Menshchikova EB, Lankin VZ, Zenkov NK, Cooper IA, Circular NF, Trufakin VA. Oxidative stress. Prooxidants and antioxidants. [Окислительный стресс. Прооксиданты и антиоксиданты] Moscow: Slovo; 2006. Russian.

38. Brieger K, Schiavone S, Miller FJ, Krause KH. Reactive oxygen species: from health to disease. Swiss Med Wkly; 2012.

39. Limon-Pacheco J, Gonsebatt ME. The role of antioxidants and antioxidant-related enzymes in protective responses to environmentally induced oxidative stress. Mutation Research. 2009;674: 137-47.

40. Ahmad A, Shameem M, Husain Q. Relation of oxidant-antioxidant imbalance with disease progression in patients with asthma. Ann Thorac Med. 2012;7: 226-32.

41. Singh S, Verma SK, Kumar S, Ahmad MK, Nischal A, Singh SK, Dixit RK. Evaluation of oxidative stress and antioxidant status in chronic obstructive pulmonary disease. Scandinavian Journal of Immunology. 2017;85(2): 130-7.

42. Kovaleva OM, Herasymchuk NM, Safarhalina-Kornilova NA. Level of 8-isoprostane and activity of superoxide dismutase and catalase in patients with hypertension with overweight and obesity against the background of combination antihypertensive therapy. Ekperement $\mathrm{i}$ klin med. 2013;2(59): 86-92. Ukrainian.

43. Pawluk H, Pawluk R, Robaczewska J, KędzioraKornatowska K, Kędziora J. Biomarkers of antioxidant status and lipid peroxidation in elderly patients with hypertension. Redox Report. 2017;22(6): 542-46. 